NBER WORKING PAPER SERIES

\title{
WHY FIRMS ADOPT ANTITAKEOVER ARRANGEMENTS
}

\author{
Lucian Arye Bebchuk \\ Working Paper 10190 \\ http://www.nber.org/papers/w10190 \\ NATIONAL BUREAU OF ECONOMIC RESEARCH \\ 1050 Massachusetts Avenue \\ Cambridge, MA 02138 \\ December 2003
}

William J. Friedman and Alicia Townsend Friedman Professor of Law, Economics, and Finance, Harvard Law School; Research Associate, National Bureau of Economic Research. I am indebted to BJ Trach for his extremely valuable assistance in preparing this paper. For helpful conversations and suggestions, I am grateful to Bill Bratton, Marcel Kahan, Alexandra McCormack, Andrew Metrick, Lynn Stout, and participants in workshops at Harvard and the University of Pennsylvania. I also wish to thank the John M. Olin Center for Law, Economics and Business at Harvard Law School for its financial support. The views expressed herein are those of the authors and not necessarily those of the National Bureau of Economic Research.

(C)2003 by Lucian Arye Bebchuk. All rights reserved. Short sections of text, not to exceed two paragraphs, may be quoted without explicit permission provided that full credit, including $\mathbb{C}$ notice, is given to the source. 
Why Firms Adopt Antitakeover Arrangements

Lucian Arye Bebchuk

NBER Working Paper No. 10190

December 2003

JEL No. G30, G34, K22

\section{$\underline{\text { ABSTRACT }}$}

Firms going public have increasingly been incorporating antitakeover provisions in their IPO charters, while shareholders of existing companies have increasingly been voting in opposition to such charter provisions. This paper identifies possible explanations for this empirical pattern. Specifically, I analyze explanations based on (1) the role of antitakeover arrangements in encouraging founders to break up their initial control blocks, (2) efficient private benefits of control, (3) agency problems among pre-IPO shareholders, (4) agency problems between pre-IPO shareholders and their IPO lawyers, (5) asymmetric information between founders and public investors about the firm's future growth prospects, and (6) bounded attention and imperfect pricing at the IPO stage.

Lucian Arye Bebchuk

Harvard Law School

1545 Massachusetts Avenue

Areeda 325

Cambridge, MA 02135

and NBER

bebchuk@law.harvard.edu 


\section{Introduction}

Strong antitakeover defenses are common among publicly traded firms. Why do firms adopt such arrangements? Does the adoption of such arrangements indicate that board veto over takeovers is beneficial to share value? What explains the fact that at the IPO stage firms adopt strong takeover provisions, such as effective staggered boards, that shareholders systematically reject midstream? To what extent should corporate law place limits on a firm's choice of antitakeover arrangements? This paper seeks to address each of these questions.

Firms opt for antitakeover protection in two main ways, both of which have attracted some attention. First, firms adopt antitakeover charter provisions. Recent work has documented that in the last decade, firms that have gone public have increasingly been incorporating such provisions in their charters. ${ }^{1}$ Second, firms incorporate in states that have statutes or case law that make takeovers difficult. Recent evidence indicates that states with more antitakeover statutes are more successful in attracting incorporations. ${ }^{2}$

Supporters of board veto have argued that the adoption of antitakeover arrangements at the IPO stage provides "market proof" that board veto is desirable for shareholders. ${ }^{3}$ Their inference is unwarranted, however, because the evidence about shareholder preferences for antitakeover protections are, to say the least, rather mixed. While the adoption of antitakeover protections at the IPO stage has

\footnotetext{
${ }^{1}$ see John C. Coates IV, Explaining Variation in Takeover Defenses: Blame the Lawyers, 89 Cal. L. Rev. 1301 (2001); Robert Daines \& Michael Klausner, Do IPO Charters Maximize Firm Value? Antitakeover Protection in IPOs, 17 J. L. Econ. \& Org. 83 (2001); Laura Casares Field \& Jonathan M. Karpoff, Takeover Defenses of IPO Firms, 57 J. Fin. 1857, 1858 (2002).

2 See Lucian Arye Bebchuk et al., Does the Evidence Favor State Competition in Corporate Law, 90 Cal. L. Rev. 1775, 1815-18 (2002); Lucian Arye Bebchuk \& Alma Cohen, Firms' Decisions Where to Incorporate, 46 J.L. \& Econ. (2003); Guhan Subramanian, The Influence of Antitakeover Statutes on Incorporation Choice: Evidence on the "Race" Debate and Antitakeover Overreaching, 150 U. Pa. L. Rev. 1795 (2002).

3 Such arguments are made in Stephen J. Choi \& Andrew T. Guzman, Choice and Federal Intervention in Corporate Law, 87 Va. L. Rev. 961, 985-86 (2001); Marcel Kahan \& Edward B. Rock, Corporate Constitutionalism: Antitakeover Charter Provisions as Precommitment, 151 U. Pa. L. Rev. (forthcoming 2003); Martin Lipton, Pills, Polls, and Professors Redux, 69 U. Chi. L. Rev. 1037 (2002); Jonathan R. Macey, Displacing Delaware: Can the Feds Do Better than the States in Regulating Takeovers?, 57 Bus. Law. 1025 (2002); Lynn A. Stout, Do Antitakeover Defenses Decrease Shareholder Wealth? The Ex Post/Ex Ante Valuation Problem, 55 Stan. L. Rev. 845, 847-56 (2002); John Elofson, What If They Gave a Shareholder Revolution and Nobody Came? Poison Pills, Binding Shareholder Resolutions and the Coase Theorem (working paper 2002).
} 
increased over the last decade, shareholder opposition to antitakeover protections through voting decisions has increased as well. ${ }^{4}$ In the wake of this seemingly contradictory evidence, a theory is needed that is sufficiently rich to account for the behavior of firms and investors, both at the IPO stage and in midstream. ${ }^{5}$

I identify and work out below several possible explanations that can account for both IPO and midstream behavior. ${ }^{6}$ First, under the explanation of encouraging de-concentration of ownership, antitakeover provisions serve the interests of shareholders when firms go public. In the absence of such arrangements, founders would be discouraged from subsequently reducing their holdings and relinquishing the lock on control that comes with concentrated ownership. Under this explanation, while public investors would fare best under dispersed ownership with weak antitakeover provisions, having strong antitakeover provisions in the IPO charter is still preferable because it results in less entrenchment. Thus, antitakeover provisions are desirable at the IPO stage only because they encourage founders to break up their control blocks. Then, once ownership is sufficiently dispersed so that the votes of public investors matter, the benefits of antitakeover protections disappear. This can explain the midstream opposition of such investors to antitakeover arrangements.

Under the efficient rent protection theory, antitakeover arrangements are always undesirable for public investors and reduce the value of their shares. However, the benefits of rent protection obtained by the founders through the antitakeover provisions are, at least at the IPO stage, greater than the resultant reduction in share price that the provisions cause. In this case, antitakeover arrangements are efficient overall; thus, assuming no informational problems, founders find it in their interest to adopt them at the IPO stage even though this

\footnotetext{
4 See Lucian Arye Bebchuk \& Allen Ferrell, Federalism and Corporate Law: The Race to Protect Managers from Takeovers, 99 Col. L. Rev. 1168, 1187 (1999); Lucian Arye Bebchuk \& Allen Ferrell, Federal Intervention to Enhance Shareholder Choice, 87 Va. L. Rev. 993, 999-1001 (2001).

${ }^{5}$ Michael Klausner, in Institutional Shareholders, Private Equity, and Anti-takeover Protection at the IPO Stage 151 U. Pa. L. Rev. (forthcoming 2003), also stresses the conflicting patterns of IPO and midstream behavior and the need to reconcile them. His analysis focuses on the firms with private equity funding, where some of the institutional investors regularly voting against antitakeover provisions are also investors in the private equity funds taking public firms with such provisions.

${ }^{6}$ As I will note, some of the suggested explanations are new, while others build on earlier works written by myself and by others. For all explanations, my analysis seeks to contribute by working out fully the explanation, examining the extent to which it can explain empirical patterns, and drawing its implications for legal policy.
} 
reduces the price they can get for their shares. At the midstream stage, however, shareholders have every reason to vote against a proposed antitakeover arrangement unless they receive appropriate compensation for the resulting reduction in the value of their shares. Similarly, if they could undo the antitakeover arrangement, shareholders would likely vote to do so in midstream.

Under agency cost explanations, antitakeover arrangements may be adopted even though they are inefficient. That is, the cost to the pre-IPO shareholders from reduced IPO revenues caused by such arrangements is smaller than the rent protection benefits they would receive. And, given that antitakeover provisions reduce share value, shareholders can be expected to vote against such arrangements in midstream. The question remains, however, as to why pre-IPO shareholders adopt such arrangements. The answer given is that agency problems on the side of the pre-IPO shareholders lead them to adopt inefficient charter provisions.

One type of agency problem is an agency problem among IPO shareholders. Here, when only some of the pre-IPO shareholders will continue to run the firm after the IPO, these founder-managers might have an incentive to include antitakeover arrangements in the charter. After all, they will fully capture the benefits of rent protection, and will bear only part of the cost of reduced IPO share price.

Another type of agency problem is an agency problem between lawyers and pre-IPO shareholders. To the extent that lawyers' expertise gives them influence over decision-making, they might have an incentive to tilt their recommendations in favor of antitakeover arrangements. The downside of not having antitakeover protection--that incumbents might find themselves unprotected from a hostile bid down the road--might be attributed to the lawyers and might negatively affect their reputation. Furthermore, the potential upside of not including antitakeover provisions--a slightly higher IPO share price--would hardly be credited to the lawyers' work. As such, since the adoption of antitakeover provisions provides a benefit to lawyers and no cost to them, they have an incentive to use their influence over the drafting of the charter to encourage antitakeover arrangements, even though these arrangements are inefficient for both founders and shareholders.

Under the asymmetric information theory, public investors are assumed to have perfect information about the effect of the provision given any value of the company's assets, but to have imperfect information about the value of these assets. In such a case, assuming that higher asset value is associated with higher expected benefits from rent protection, some or all founders will have an incentive to signal a high asset value by adopting antitakeover arrangements. Although shareholders know that antitakeover arrangements are inefficient and will reduce the share price 
at the IPO stage accordingly, the increase in share price as a result of the information conveyed concerning asset value outweighs this negative antitakeover effect. Thus, this signaling effect may provide founders with an incentive to adopt inefficient antitakeover provisions at the IPO stage. Shareholders, however, will oppose such inefficient protections in midstream.

Last, but not least, under the bounded attention theory, investors at the IPO stage do not bother to price antitakeover arrangements that fall within a certain set of conventional arrangements. The exact location of the firm's choice within this set is viewed as relatively less important than the other uncertainties involved in valuing a closely held company that is going public. Without the aid of prior market pricing and exposure to market analysis, the level of uncertainty about the value of the company's assets and management is relatively high. Furthermore, the consequences of the chosen antitakeover arrangement would have the most impact down the road after shares become more dispersed. As a result, even if investors view some antitakeover arrangements as theoretically inefficient, they might not bother to factor them into the price they are willing to pay for IPO shares.

In contrast, down the road at the midstream stage, questions concerning antitakeover arrangements will come to a vote in circumstances that make investors focus on the issue in isolation from others and that make the issue practically important. At this point, the inefficiency of antitakeover arrangements will lead shareholders to vote against them.

In addition to identifying several potentially plausible explanations for observed IPO and midstream patterns, I also discuss why some other potential explanations, including ones put forward by Marcel Kahan and Ed Rock, Lynn Stout, and Michael Klausner, cannot account for these patterns. I thus attempt to provide a comprehensive review of the factors that contribute to producing the observed patterns of behavior.

The analysis of this paper is organized as follows. Section I describes the conflicting evidence of shareholder preference for antitakeover provisions. Section II then develops and analyzes alternative explanations for the difference in behavior between the IPO and midstream stages. Section III concludes. 


\section{THE OPTIMALITY INFERENCE AND ITS SHORTCOMINGS}

\section{A. The Debate Over Board Veto in Corporate Takeovers}

There are reasons to believe that strong antitakeover protections decrease share value, and I review them in detail elsewhere. ${ }^{7}$ Ex post--that is, once a bid is on the table--incumbents can use their veto power to block an acquisition that would be beneficial to shareholders. The evidence indicates that incumbents armed with a staggered board are much more likely to retain independence in the face of a hostile bid, and that the decision to remain independent commonly makes shareholders worse off. 8

Furthermore, ex ante, having a board veto reduces the disciplinary force that the takeover threat can exert on incumbents. The evidence indicates that, when managers are protected from takeovers by strong antitakeover statutes or by antitakeover provisions, managerial slack increases. ${ }^{9}$ When managers have less to fear from takeovers they fail to reduce costs and have poorer operating performance, including lower profit margins, return on equity, and sales growth.

Are there any potential benefits of board veto that outweigh the above costs of it? Supporters of board veto argue that that, even if incumbents might abuse their veto power in hostile bid cases, they are likely to use it to benefit shareholders by raising premia in negotiated transactions. ${ }^{10}$ As I explain in detail elsewhere, however, there are good theoretical reasons to doubt the presence, or at least the significance, of the bargaining advantage that a board veto is claimed to have. ${ }^{11}$ In a preliminary empirical study of this question, Coates, Subramanian, and I indeed found no statistically significant effect of staggered boards on premia in negotiated

7 See_Lucian Bebchuk, The Case Against Board Veto in Corporate Takeovers, 69 U. Chi. L. Rev. 973 (2002).

8 See Lucian Bebchuk et al., The Powerful Antitakeover Force of Staggered Boards: Theory, Evidence, and Policy, 54 Stan. L. Rev. 887 (2002).

${ }^{9}$ See Marianne Bertrand \& Sendhil Mullinathan, Is There Discretion in Wage Setting? A Test Using Takeover Legislation, 30 Rand J. Econ. 535 (1999); Gerald T. Garvey \& Gordon Hanka, Capital Structure and Corporate Control: The Effect of Antitakeover Statutes on Firm Leverage, 54 J. Fin. 519 (1999); Paul A. Gompers et al., Corporate Governance and Equity Prices, Q. J. E. 107, 129 (2003). 10 See, e.g., Mark Gordon, Takeover Defenses Work. Is That Such a Bad Thing?, 55 Stan. L. Rev. 819, 824-25 (2002).

11 See Bebchuk, supra note 7, at 1007-1013. 
acquisitions. ${ }^{12}$ Furthermore, two recent studies find evidence that managers are willing to trade off premia for personal gains in the wake of a takeover, ${ }^{13}$ which further reinforces doubts that giving managers more bargaining power would result in more value to shareholders.

Proponents of board veto have also argued that it might have beneficial effects ex ante. They suggest that board veto can encourage long-range investment and prevent managerial myopia. ${ }^{14}$ They also claim that board veto can encourage firm-specific investments by managers (and other employees). ${ }^{15}$ As I explain elsewhere, however, there is currently no empirical support for the view that these conjectured effects are sufficiently significant to outweigh the adverse ex ante effects of board veto. ${ }^{16}$

A current study by Alma Cohen and myself investigates empirically the overall effect that board veto has on shareholder value. ${ }^{17}$ We find that staggered boards established by company charters are associated with a lower market value, with a median reduction of about $5 \%$ of market value. We also find evidence consistent with charter-based staggered boards causing, and not merely reflecting, a lower firm value. This evidence provides support for the view that board view has overall an adverse effect on shareholders.

Thus, in terms of direct evidence about the effects of board veto, supporters of board veto have no favorable empirical evidence to reply on and confront a significant body of unfavorable empirical evidence. It is thus unsurprising that proponents of board veto now so much welcome and try to rely on certain indirect

\footnotetext{
12 Bebchuk et al., The Powerful Antitakeover Force of Staggered Boards: Further Findings and a Reply to Symposium Participants, 55 Stan. L. Rev. 885 (2002).

13 See Jay Hartzell et al., What's in It for Me?: Personal Benefits Obtained by CEO's Whose Firms Are Acquired 5 (2003) (New York University Stern School of Business working paper), at http://www.stern.nyu.edu/ eofek/papers.htm (last visited Sep. 7, 2003); JulieWulf, Do CEOs in Mergers Trade Power for Premium?: Evidence from "Mergers of Equals" (working paper, at http:// knowledge.wharton.upenn.edu/PDFs/1009.pdf).

14 See e.g., Martin Lipton, Takeover Bids in the Target's Boardroom, 35 Business Lawyer 101, 115-16 (1979); Martin Lipton and Steven Rosenblum, A New System of Corporate Governance: The Quinquennial Election of Directors, 58 University of Chicago Law Review 187, 205-14 (1991).

15 See, e.g., Lynn Stout and Margaret Blair, 85 Virginia Law Review 247, 304-05 (1999).

16 See Bebchuk, supra note 7, at 1011-13.

17 See Alma Cohen and Lucian Bebchuk, The Costs of Entrenched Boards, working paper, Harvard Law School, October 2003.
} 
evidence -- the evidence that companies adopt antitakeover provisions at the IPO stage.

\section{B. IPO Behavior and Optimality}

Although state corporate law has, for the most part, sanctioned the various elements of board veto, it has by no means mandated these elements. Corporate charters could seek to tie management's hands from blocking offers by restricting board power to use poison pills. Alternatively, corporate charters could provide arrangements that reinforce the pill by making it more difficult for a hostile bidder to replace the board with a team that would redeem the pill. Recent empirical evidence that has attracted much attention indicates that firms going public during the past decade have designed their charters to support, rather than eliminate, board veto. ${ }^{18}$

To begin, while state law universally recognizes the validity of the poison pill, charters routinely authorize the use of blank check preferred stock that is used for creating poison pills. This practice is not surprising, however, for the poison pill by itself does not result in board veto and is probably not, on its own, value-decreasing. The poison pill still allows shareholders to decide whether to authorize the takeover; it merely forces them to express their preferences through a vote on replacing the directors.

Although the ability to force a shareholder vote through the poison pill is not by itself value-decreasing, there are other antitakeover protections--those that substantially impede the ability of shareholders to replace the board quickly--that can provide management with substantial veto power. In particular, the combination of the poison pill and an effective staggered board provides management with considerable veto power. Unlike the poison pill, which can be adopted at any time by the board and does not require shareholder approval, staggered boards usually require a charter provision.

Empirical evidence suggests that IPO firms opted for staggered boards and other antitakeover provisions at an increasing rate throughout the 1990s. For instance, in his comprehensive study of IPO charter provisions, Coates found that only thirty-four percent of firms adopted staggered boards at the IPO stage in 199192. By 1998, that number had risen to sixty-six percent, and by 1999 the number rose again to eight-two percent of firms. ${ }^{19}$

\footnotetext{
18 See sources cited supra note 1 .

${ }^{19}$ Coates, supra note 1 , at 1376.
} 
According to a widely held view, firms at the IPO stage have powerful incentives to adopt arrangements that benefit shareholders, ${ }^{20}$ and the adoption of arrangements at this stage thus provides evidence of their optimality. Applying this general view to the takeover context, supporters of board veto argue that this pattern was due to--and thus was evidence of --the positive effects of board veto on share value. ${ }^{21}$ According to this view, the IPO evidence indicates that shareholders--who are in the best position to know their interests--wish to implement board veto. The existing direct evidence concerning the adverse effects of board veto, it is argued, should take a back seat to the clear expression of shareholder preferences that IPO charters provide.

\section{Conflicting Midstream Behavior}

The evidence with respect to shareholders' preferences, however, is much more mixed than supporters of board veto would like to believe. Indeed, while IPO charter provisions are argued to enable an inference of shareholder preferences, shareholders have been expressing their preferences directly and clearly in their voting decisions.

Throughout the past decade, shareholders of existing companies have been generally unwilling to vote in favor of amending the charter to include antitakeover provisions that would make replacement of the board more difficult. In the wake of this dwindling shareholder support, boards have all but stopped proposing such amendments. From 1986 to 2000, the annual number of such proposals dropped by ninety percent. ${ }^{22}$

Furthermore, shareholders' opposition to antitakeover charter provisions has been reflected in the large and growing support given to precatory resolutions to dismantle existing staggered boards. ${ }^{23}$ For instance, Patrick McGurn, Special Counsel for Institutional Shareholder Services, has stated:

In the wake of the corporate scandals of the past several months, ISS often receives inquiries as to our views on the two or three key governance changes that -if adopted by all issuers --would help investors to avoid similar market meltdowns

20 See Michael C. Jensen \& William H. Meckling, Theory of the Firm: Managerial Behavior, Agency Costs, and Ownership Structure, 3 J. Fin. Econ. 305 (1976).

21 See sources cited supra note 3.

22 See Klausner, supra note 3, at 6-7.

23 See Georgeson Shareholder, Annual Corporate Governance Review: Shareholder Proposals and Proxy Contests 6 (2002). 
in the future. Unquestionably, the item on our wish list that draws the blankest stares from corporate America is the call for annual elections of all members of corporate boards. ${ }^{24}$

McGurn goes on to note that over the last three years, precatory resolutions to repeal staggered boards have, on average, received support from a majority of the shareholders participating in the vote. ${ }^{25}$ The evidence shows that this support is strong and has been increasing over the last decade.

That these proposals have been able to gain a majority is particularly striking due to the tendency of shareholders to side with the board in votes on precatory resolutions. Many other such resolutions, even those that are potentially beneficial for shareholders, receive little institutional support. ${ }^{26}$ But on the issue of staggered boards, the institutional shareholders speak loudly, persistently, and with a clear voice. This pattern provides very strong evidence that shareholders do not favor charter provisions that facilitate board veto.

\section{Attempting to Reconcile IPO and Midstream Behavior}

Can supporters of board veto reconcile the shareholder voting evidence with their claim that shareholders often prefer a board veto? Marcel Kahan an Ed Rock raise the possibility that it may take time for shareholders to learn about the precise effects of board veto on share value. ${ }^{27}$ According to this view, shareholder voting against takeover defenses is a transient phenomenon that will gradually go away as all shareholders learn to recognize the beneficial effects of such defenses.

This explanation, however, is undermined by an examination of the trends over time. During the 1990s, the incidence of antitakeover provisions in IPO charters has been increasing, as has the percentage of shareholders voting in opposition to staggered boards. Under the learning conjecture, learning should gradually lead to convergence of IPO and midstream behavior; but, in fact, we have seen the opposite. As players' experience with antitakeover provisions has increased, both the IPO adoption and the midstream opposition have become more pronounced.

\footnotetext{
24 Patrick S. McGurn, Classification Cancels Corporate Accountability, 55 Stan. L. Rev. 839, 839 (2002).

$25 \mathrm{Id}$. at $840-41$.

${ }^{26}$ See Georgeson Shareholder, Annual Corporate Governance Review: Shareholder Proposals and Proxy Contests.

${ }^{27}$ See Kahan and Rock, supra note 3, at 8-9.
} 
Kahan and Rock also suggest that strong antitakeover protections are beneficial for some companies but not for others. ${ }^{28}$ According to this view, IPO adoption of antitakeover arrangements is limited to companies of the former type that go public, while midstream opposition to such arrangements occurs in firms of the latter type. This heterogeneity-based explanation, however, is also undermined by the evidence.

For one thing, IPO adoption of antitakeover arrangements has become practically universal rather than limited to certain types of companies. The incidence of staggered board adoption at the IPO stage has been increasing considerably and now exceeds eighty percent. ${ }^{29}$ At the same time, shareholders' midstream opposition to staggered boards is also practically universal rather than limited to some types of companies. To be sure, precatory resolutions to dismantle staggered boards--which are non-binding anyway--occur in only a limited fraction of companies. In many companies that do not have a staggered board, management would have been happy to get a charter provision establishing a staggered board if it could, but it cannot do so because of shareholders' unwillingness to approve such charter amendments.

Could one argue that existing companies without a staggered board are of a type for which a staggered board is not beneficial, rather than of a type for which a staggered board is beneficial? That would be implausible because the selection of existing companies that do not have staggered boards does not reflect their current type. Most publicly traded companies went public prior to 1990, and since 1990 companies that did not already have a staggered board have been unable to get shareholders to approve the adoption of a staggered board. The absence of staggered boards in existing pre-1990 companies reflects at most their pre-1990 type rather than their current type. The inability of such companies to obtain shareholder support for a charter amendment establishing a staggered board thus indicates that shareholder opposition to midstream adoption of such an amendment is universal rather than specific to some types of companies.

Lynn Stout argues against inferring from shareholders' voting decisions that shareholders do not benefit from antitakeover arrangements. ${ }^{30}$ On her view, such arrangements benefit shareholders by encouraging managers (and other employees)

\footnotetext{
${ }^{28}$ See_Kahan \& Rock, supra note 3.

${ }^{29}$ See SharkRepellent.Net, IPO year in Review 2002, available at www.sharkrepellent.net.

30 Lynn Stout, The Shareholder as Ulysses: Some Empirical Evidence on Why Investors in Public Corporations Tolerate Board Governance, University of Pennsylvania Law Review _ (2003), manuscript at 37-40.
} 
to make firm-specific investments in human capital, and IPO firms adopt them for this reason. Once shareholders derive some benefits from managers' making such sunk-cost investments, she argues, they may be tempted sometimes to try to remove takeover defenses. But this argument cannot explain why the large fraction of existing firms that did not have a staggered board in 1990 have generally been unable since 1990 to persuade shareholders to add such a defense. If the shareholders of IPO firms generally benefit from takeover defenses that will encourage firm-specific investments in the years following the IPO, we should also expect that the shareholders of many existing companies will also benefit from adopting defenses that will encourage firm-specific investments in the years following the adoption. But shareholders of existing firms have generally been unwilling to vote in favor of adding such defenses.

I conclude that it is not possible to accept the simple Panglossian theory that the common adoption of antitakeover provisions in IPO charters indicates that shareholders prefer to have such arrangements. The view that IPO charters simply seek to satisfy shareholders' wishes to have companies governed by antitakeover provisions is inconsistent with shareholders' midstream strong and persistent opposition to such provisions. What is needed, then, is a richer account that can explain both IPO and midstream behavior. Investigating what such an account might be is the task of the next section, which identifies several explanations for the complex empirical reality that we observe.

\section{EXPLAINING IPO AND MIDSTREAM BEHAVIOR}

\section{A. A Simple Model}

In order to explore the incentive effects facing firms and shareholders--both at the IPO stage and midstream--it is helpful to consider a paradigmatic, stylized model. This model will be useful for analyzing the various possible theoretical explanations for the empirical data described above--namely the efficiency theory, the agency cost theory, and the signaling theory.

The model contains three different time periods. In the first period, $T_{0}$, the founders of a company are taking the company public. The founders have decided to sell only a fraction, $\alpha$, of their shares. I assume that, as is common in IPOs, the fraction $\alpha$ amounts to a minority of the shares, so that immediately after the IPO the pre-IPO shareholders still hold a majority of the shares. The founder-manager 
running the firm prior to the IPO is expected to continue running the firm after the IPO.

When the founders take the company public, they must also choose whether to incorporate antitakeover charter provisions in the IPO charter. For simplicity, I will assume that the choice made is between an arrangement, $B V$, under which the board has veto power over takeover bids, and an arrangement, No- $B V$, under which the board will not have such veto power. Because this choice might affect the value of public investors' shares in the event that the company moves to dispersed ownership down the road, this choice might also affect the price paid for shares at the IPO. Let $P$ denote the price that public investors are willing to pay for the fraction $\alpha$ of the shares under a No-BV arrangement, and let $P+\Delta P$ denote the price they would be willing to pay for the shares under a $B V$ arrangement.

In the second period, $T_{1}$, there is a probability, $\theta$, that the manager of the firm will face a profitable investment opportunity. To finance such an expansion, the firm would need to raise an amount, $K$, in a secondary offering of shares. The investment would produce a value of $K+\Delta K$ (where $\Delta K$ is positive). It is assumed that the amount needed is sufficiently large that, if the expansion is pursued, the founders would no longer have a majority of the votes and thus would not have a lock on control. This would make the initial choice between $B V$ and No-BV relevant. Such a development will be referred to as "a move to dispersed ownership."

In the third period, $T_{2}$, the company operates its business. If the company did not expand in $T_{1}$, the company will produce a cash flow of $V$ for its shareholders and a private benefit of $B$ for its manager. If the company did expand and move to dispersed ownership, the values captured by the shareholders and the manager will depend on whether $B V$ or No- $B V$ was initially chosen.

If the company adopted a $B V$ arrangement at the IPO, the manager will be able to continue to enjoy a private benefit of $B$ even though the company is now in dispersed ownership. In contrast, under No- $B V$ and dispersed ownership, the manager will be able to enjoy only a lower level of private benefits, $B-\Delta B$. Thus, $\Delta B$ is the positive effect on private benefits that antitakeover protection provides. This effect is comprised of the security of getting the private benefits of office, or the extra benefits that the manager would be able to extract without fear of a takeover.

With regard to cash flow, under a $B V$ arrangement the cash flow captured by shareholders will be $V+K+\Delta K$. In this case, even though private benefits are assumed not to decline, cash flow will increase because of the expansion. A No-BV arrangement, which would reduce private benefit by $\Delta B$, would increase cash flows by $\Delta V$. While we have every reason to assume that $\Delta B$ is positive--that not having 
takeover protection will reduce the manager's private benefits--I make no assumptions about $\Delta V$. If antitakeover protection benefits shareholders--due, for instance, to increased bargaining power for the board or decreased pressure to focus on short-term results-- $\Delta V$ will be negative. That is, a No- $B V$ arrangement will result in lower cash flows. In contrast, if the antitakeover protection reduces cash flows -due, for instance, to increased shirking or extraction of benefits by management-- $\Delta V$ will be positive. The question of whether antitakeover protection enhances share value is therefore equivalent to the question of whether $\Delta V$ is negative.

\section{B. Efficiency-Based Explanations}

\section{Inducement to De-concentrate Ownership}

Under this theory, although $B V$ has a negative effect on shareholders when there is dispersed ownership, shareholders are even worse off when the company does not move to dispersed ownership. Thus, under this explanation, shareholders prefer $B V$ in the IPO charter at $T_{0}$ because, in the event that a profitable investment opportunity emerges, it will encourage the firm to raise capital and to move to dispersed ownership at $T_{1}{ }^{31}$

The value of minority shares in the company will be lower if the company does not move to dispersed ownership than it will be under dispersed ownership. In our model, the increase in value comes from the fact that the investment opportunity is a profitable one and the public investors share in the value of it. Furthermore, although we have assumed for simplicity that the manager enjoys the same high level of private benefits under either dispersed or concentrated ownership when operating under a $B V$ arrangement, this might often not be the case. the lock on control when the founders maintain a controlling block of shares is stronger than their lock on control under $B V$ with dispersed ownership.

Let us suppose that $\Delta V$ is positive. In this case, if public investors could count on the company moving to dispersed ownership in the event that a profitable opportunity arises, they would prefer to have a $N o-B V$ arrangement, and would be willing to pay a higher price at the IPO for their shares under $N o-B V$ than under $B V$.

\footnotetext{
${ }^{31}$ The analysis in this section builds on Lucian A. Bebchuk, A Rent-Protection Theory of Corporate Ownership and Control (Nat'l Bureau of Econ. Research, Working Paper No. 7203, 1999). This paper establishes that controlling shareholders might be discouraged from making efficient moves to dispersed ownership when such a move would reduce their private benefits of control.
} 
Getting to dispersed ownership is not a certainty, however, and the likelihood of getting to dispersed ownership might depend on whether the company has chosen a $B V$ arrangement.

At $T_{1}$, the controller will clearly elect to expand if the initial arrangement chosen is $B V$. The expansion will not reduce private benefits and will increase the cash flows that will be captured by the initial shareholders, including the founders. The expansion will increase cash flows by $K+\Delta K$, but to raise the needed $K$ it will be necessary to provide claims to cash flow in the amount of $K$. Thus, the initial postIPO shareholders--the founders and the shareholders purchasing shares at the IPO-will gain an amount of $\Delta K$, and the founders will capture a fraction (1- $\alpha$ ) of this gain.

In contrast, under a No-BV arrangement, the manager might elect not to pursue an efficient expansion opportunity if one emerges. Under $N o-B V$, the expansion will reduce private benefits by $\Delta B$, a cost that the manager will fully bear. The expansion will also increase the cash flows captured by the initial shareholders by $\Delta K+\Delta V$, but the founders will capture only a fraction $(1-\alpha)$ of this increase. Thus, because the manager will bear the full cost of the expansion in terms of forgone private benefits but will not fully capture the benefits in terms of increased cash flows, the manager's private interests might best be served by rejecting the efficient investment opportunity. This will occur if

$$
\begin{aligned}
& (1-\alpha)(\Delta K+\Delta V)-\Delta B<0 \\
& \text { or, alternatively stated, if } \\
& \Delta K+\Delta V-\Delta B<[\alpha /(1-\alpha)] \Delta B .
\end{aligned}
$$

Thus, if this condition is satisfied, the shareholders will prefer a $B V$ arrangement to a $N o-B V$ arrangement even though $\Delta V$ is positive and a $N o-B V$ arrangement would increase the value of shares under dispersed ownership. When this condition is satisfied, the company will not reach dispersed ownership if No-BV is chosen, and the effect of No-BV in such a case is thus irrelevant.

In the simple model that I use, because the profit from an efficient expansion opportunity is fixed at $\Delta K$, the adoption of a No- $B V$ arrangement will either prevent efficient expansion or will have no effect on the likelihood of such expansion. In a more general model, in which there is a distribution of possible values for $\Delta K$, a No$B V$ arrangement will prevent efficient expansion when the value of $\Delta K$ is small enough but not when the value of $\Delta K$ is large enough. In such a case, the cost of a 
$N o-B V$ arrangement is that it will reduce the likelihood of efficient expansion and a move to dispersed ownership. This cost might lead buyers of shares at the IPO to prefer, and to be willing to pay more for, shares with a $B V$ arrangement.

Thus, the effect of $B V$ arrangements on the likelihood of a subsequent move to dispersed ownership might make such an arrangement preferable for buyers of shares at the IPO stage. This could explain the adoption of $B V$ in the IPO charter. Such an adoption would increase the value that buyers would be willing to pay for the fraction $\alpha$ of the shares sold, and at the same time would maintain the value of the founders' block in the event that the company later moves to dispersed ownership. This explanation is also consistent with the midstream opposition to $B V$ arrangements. Once a company moves to dispersed ownership, and public investors' votes become important, the effect of $B V$ on the likelihood of a move to dispersed ownership is irrelevant. At this stage, as long as $\Delta V$ is negative, shareholders will have an incentive to vote against amendments to adopt $B V$ arrangements and to attempt to remove existing $B V$ arrangements should the opportunity arise.

Assuming that this explanation accounts for the IPO adoption of $B V$ arrangements, what does this tell us about antitakeover policy? It suggests that, when $B V$ arrangements are adopted at the IPO stage, they perform an efficient role and such adoption should be permitted and respected. Otherwise, firms would be discouraged from making efficient investments that require a move to dispersed ownership, or would be forced to resort to less efficient alternatives such as the issuance of dual class stock. At the same time, however, this explanation also implies that $B V$ arrangements reduce the value of shares in companies that already have dispersed ownership. Thus, $B V$ arrangements should not be used as a default, and should not be imposed in midstream (as has been done by some courts and legislatures) on dispersed shareholders of existing companies that did not explicitly include such arrangements in their IPO charters.

\section{Efficient Rent Protection}

Let us now put aside the first explanation considered above and assume that the company will move to dispersed ownership whenever an efficient opportunity to expand arises. Under an efficient rent protection theory, $\Delta V$ is assumed to be positive, so that the value of shares under dispersed ownership is lower with a $B V$ arrangement. However, the reduction in cash flow $\Delta V$ is smaller than $\Delta B$, the increase in private benefits enjoyed by the manager under a $B V$ arrangement. Thus, 
even with a move to dispersed ownership, the use of a $B V$ arrangement is overall efficient.

Under this explanation, public investors will be willing to pay less for shares both at the IPO stage and in the subsequent second offering stage. The founders will nonetheless be willing to bear this cost because the benefit to them of capturing higher private benefits will outweigh the costs of having a lower value attached by public investors to shares in the company.

The efficient rent protection hypothesis can help explain the empirical data. Under this theory, we should expect founders to include antitakeover provisions in IPO charters because, even after "fully paying" for their higher private benefits enjoyed under $B V$ arrangements, they will be better off retaining these higher benefits. However, given that the effect of $B V$ arrangements on public investors is negative, we would expect them to reject a move to such arrangements midstream, and to vote to remove them when the opportunity to do so arises.

If $B V$ arrangements produce an overall efficient increase in private benefits, one might wonder why managers of existing companies with such arrangements do not "bribe" shareholders to approve an antitakeover charter amendment--i.e., offer to pay a certain amount to the company if the shareholders approve such an amendment. One possible explanation is that managers might be concerned that offering to make such a side payment could be regarded as a violation of fiduciary duties. Second, at later stages in the life of mature companies, managers might have cash constraints that prevent such a payment. When founders reduce their ownership over time not by selling their own shares and keeping the proceeds, but rather by raising more capital for the firm through issuing more shares, the foundermanager might not have enough cash to purchase shareholders' consent to move to a $B V$ arrangement.

The two efficiency-based explanations thus far explored have different empirical implications that can provide the basis for empirical testing. Under the explanation based on incentives to de-concentrate ownership, a $B V$ arrangement has a positive effect on the value of public investors' shares immediately following the IPO. Share value (as measured, say, by Tobin's $Q$ ) should thus be higher for firms with $B V$ provisions than for firms without such provisions. In contrast, under the efficient rent protection theory, a $B V$ arrangement has a negative effect on the value of public investors' shares immediately following the IPO. Thus, share value should be lower for firms with $B V$ provisions than for firms without such provisions.

As for policy implications, the efficient rent protection theory and the explanation based on incentives to de-concentrate ownership have similar implications. Under the efficient rent protection explanation, because $B V$ provisions 
at the IPO can increase the overall pie, adopting them in the IPO should be permitted. In the absence of explicit charter authorization of a $B V$ arrangement, however, the default arrangement should be one of $N o-B V$. Under the considered explanation, as long as public investors are not compensated for such a change, a move to a $B V$ regime makes them worse off. Thus, the legal rules that imposed BV arrangements on shareholders of existing firms could not have been justified as an attempt to protect and benefit these shareholders.

\section{Agency-Based Explanations}

Under the two explanations set forth above, the founders--the pre-IPO shareholders--benefited overall from the adoption of a $B V$ arrangement in the IPO charter. In contrast, under the set of explanations to which I now turn, such an adoption makes the pre-IPO shareholders worse off as a group. Nonetheless, agency problems lead these shareholders to make an adoption decision that leaves them with a smaller pie overall. The first such explanation focuses on agency problems among the firm's founders. The second such explanation focuses on agency problems between the founders and their lawyers.

\section{Agency Problems Among Pre-IPO Shareholders}

Consider a situation in which the founders of a company consist of five shareholders with equal holdings, all of whom are members of the same extended family. One of the members manages the firm and is expected to continue to do so after the IPO, while the other members conduct a life of leisure and philanthropic activities. In this case, the interests of the shareholder-manager, who might have a dominant influence on the design of the IPO, are different from - and in particular, are more favorable to a $B V$ arrangement than -- the interests of the other pre-IPO shareholders. ${ }^{32}$

The reason for these divergent interests is the ability of the shareholdermanager to capture $100 \%$ of the higher private benefits that a $B V$ arrangement would produce. In contrast, the shareholder-manager would not fully bear the costs of such an arrangement to the pre-IPO shareholders. These costs, which stem from lower future cash flow and, correspondingly, lower prices for shares sold at the IPO stage and at the second public offering, will be shared by all the pre-IPO

\footnotetext{
${ }^{32}$ See Field and Karpoff, supra note 1, at 1885-6.
} 
shareholders. The shareholder-manager would bear only twenty percent of these costs.

Thus, because the shareholder-manager would capture $100 \%$ of the benefits of a $B V$ arrangement to the group of pre-IPO shareholders but would bear only twenty percent of the arrangement's costs to this group, the shareholder-manager might prefer to include this arrangement even if it would reduce the overall wealth of the group. Essentially, the distortion arises from the fact that the shareholder-manager might ignore the external cost that the adoption of a $B V$ arrangement may impose on the other pre-IPO shareholders.

The question raised by this explanation, of course, is why the other founders do not prevent such an agency problem from occurring. If a $B V$ arrangement would make them worse off, why would they not prevent the shareholder-manager from adopting it or, alternatively, "bribe" this shareholder-manager not to do so? The answer may be that the other shareholders might sometimes be passive and uninformed, and thus have little ability to control or monitor the decisions of the shareholder-manager with respect to many of the fine points of the IPO design.

This explanation, like the others, is one under which the optimal default in the absence of a charter provision to the contrary is that of a No- $B V$ arrangement. However, unlike the two efficiency-based explanations discussed above, this explanation does not imply that it is desirable to permit IPO charters to adopt $B V$ arrangements. To the extent that such arrangements are adopted due to an agency problem, such adoption cannot be expected to produce efficiency benefits.

A recent study by Field and Karpoff provides evidence that is consistent with the considered agency problems playing a role in the IPO adoption of antitakeover protections. The study finds that, during the 1988-1992 period, the likelihood that a firm going public adopted antitakeover provisions was inversely related to the fraction of the pre-IPO shares held by the manager. ${ }^{33}$ The smaller this fraction, of course, the greater the incentive of the manager to include antitakeover provisions even if they are value-decreasing. The study also finds that the likelihood of antitakeover provisions was positively related to various parameters that are correlated with greater power to the manager at the time of the IPO. ${ }^{34}$

\footnotetext{
${ }^{33}$ See id. at $1870-71$.

${ }^{34}$ See id. at 1869-71.
} 


\section{Agency Problems Between Pre-IPO Shareholders and Lawyers}

Another possible agency problem could be an agency cost between the preIPO shareholders and their lawyers. In making the choice between a $B V$ and a No$B V$ arrangement, the founders may defer to the recommendation of counsel. Lawyers, in turn, might have distorted incentives to prefer a $B V$ over a No-BV arrangement even if a No-BV arrangement would be somewhat better for the preIPO shareholders.

Founders taking their company public may elect to defer to counsel with respect to the choice between $B V$ and $N o-B V$ because of their recognition that counsel might have superior information and expertise. In particular, the lawyers-with their greater expertise in advising public companies--might have better information about the effects of $B V$ or $N o-B V$ arrangements down the road. Furthermore, lawyers might be perceived to have a better understanding of the effect of $B V$ or No-BV arrangements on the price that public investors would be willing to pay for shares. Indeed, recent empirical evidence indicates that counsel is likely to have significant influence on the design of charter at the IPO stage. ${ }^{35}$

The fact that founders may defer to lawyers' superior information creates a potential for agency costs. The very reason why founders might wish to rely on the lawyers' recommendation implies that founders will not be able to fully monitor whether lawyers are giving them the right recommendation (one that reflects the lawyers' undistorted judgment). Because lawyers have some discretion, the lawyers' own incentives might influence the recommendation they ultimately provide. ${ }^{36}$

Lawyers' incentives point toward favoring $B V$ over No- $B V$. The reason for this is that lawyers can expect to feel the costs of a No-BV arrangement more than its benefits. As to costs, a No- $B V$ choice means a greater likelihood that down the road, the company will be taken over and the lawyer will lose a valuable client. Furthermore, the lawyer may suffer reputational costs as a result of its client being

\footnotetext{
35 See Coates, supra note 1. See also Robert Daines, The Incorporation Choices of IPO Firms, 77 N.Y.U. L. Rev. 1559 (2002).

${ }^{36}$ This problem is not unlimited, however. The lawyers can only affect the decision of the founders within a range of reasonable options. Each client will have a set of reasonable options--likely those most often utilized in the market--between which they cannot distinguish. It is among these indistinguishable options that lawyers can influence decisions, and may be motivated by their own incentives rather than those of the founders.
} 
taken over without difficulty. If managers find themselves without takeover defenses, they might well blame their lawyers.

In contrast, the benefits of a No-BV arrangement, which stem from a slightly higher IPO price, may not be visible and, more important, are unlikely to be attributed to the lawyer if visible. The founders are not going to observe the extra value obtained by the use of a No-BV arrangement. And, in any event, the professional assessment of the lawyers' work is unlikely to be much affected by the IPO price.

To illustrate this point consider a situation in which, for whatever reason, both $B V$ and No-BV arrangements have become viewed as conventional and standard, and each type of arrangement is used by a substantial fraction of the companies going public. At this point, we can expect to see tipping in the direction of increased use of $B V$ arrangements, because lawyers would have less to lose from recommending a $B V$ arrangement than from recommending a No- $B V$ arrangement.

The evidence is consistent with this analysis. In the early 1990s, there were a substantial number of IPO firms that included antitakeover provisions in their charter, but also a substantial number of firms that did not. ${ }^{37}$ According to a study by Coates, firms elected to adopt $B V$ arrangements in their charter provisions at increasing rates throughout the 1990s; by the end of the decade, a great majority of IPO charters had adopted staggered boards. ${ }^{38}$

Coates views this trend as evidence of an agency problem that differs from the one on which I focus. ${ }^{39}$ In his view, the adoption of a $B V$ arrangement at the IPO stage was good for pre-IPO shareholders, and the reason why some firms did not adopt $B V$ arrangements was that their lawyers were not doing their job well. Over time, even bad lawyers caught up and learned to serve their clients well by adopting $B V$ arrangements. The evidence, however, is also consistent with a different account. Under the account considered in this section, pre-IPO shareholders were best served by not including a $B V$ arrangement, and lawyers deviated from their clients' interests when they recommended $B V$ rather than when they recommended No- $B V$. Over time, lawyers increasingly switched to recommending a $B V$ arrangement since this was the safest route for them--it produced the smallest likelihood that their clients would complain about the legal advice they received.

Finally, I should note that the policy implications of this account are similar to those of the first agency-based explanation. Like the first explanation, this

\footnotetext{
${ }^{37}$ See Coates, supra note 1 , at 1358-60.

${ }^{38}$ See id. at $1375-76$.

39 See id. at 1377-1383.
} 
explanation implies not only that $N o-B V$ is the best default arrangement, but also that the adoption of $B V$ charter provisions does not necessarily imply that they will produce efficiency benefits and thus should be permitted.

\section{Information-Based Theories}

\section{Asymmetric Information}

Under this explanation, it is common knowledge among founders and public investors at the IPO stage that, in the event the company converts to dispersed ownership, a $B V$ arrangement would be inefficient compared with a No- $B V$ arrangement. However, while both founders and public investors have the same information about the identity of the efficient arrangement, founders have some private information about the magnitude of the benefits to them and the costs to public investors of the $B V$ arrangement. In a model developed in a companion piece, I show that such asymmetry of information might lead founders to adopt inefficient provisions at the IPO stage. ${ }^{40}$

To appreciate the intuition, consider the following numerical example. Suppose that firms going public sell thirty percent of their shares, and that such firms are equally likely to be either of high-value type $H$, or low-value type $L$. Founders know their firm's type but public investors do not. $H$ and $L$ firms differ in the likelihood of having an investment opportunity that will lead them to move to dispersed ownership. For simplicity, suppose that $H$ firms have a $100 \%$ likelihood and $L$ firms have a $10 \%$ likelihood of facing such an opportunity. Suppose also that, when an opportunity emerges, it will be sufficiently profitable that the foundermanager will pursue it under either a $B V$ or a No- $B V$ arrangement. Finally, suppose that a $N o-B V$ arrangement will be less efficient (i.e., $\Delta V>\Delta B$ ). ${ }^{41}$

Even though investors know that a No-BV arrangement is efficient for both $H$ and $L$ firms, it can be shown that an efficient pooling equilibrium--one in which both types of firms go public with a No-BV arrangement--might not exist. In such

\footnotetext{
40 Lucian Arye Bebchuk, Asymmetric Information and the Choice of Corporate Governance Arrangements, Harvard Olin Discussion Paper No. 398 (2002), at http:/ / papers.ssrn.com/abstract_id=327842.

${ }^{41}$ In the model of Bebchuk, supra note $40, H$ and $L$ differ in the value of their assets rather than in the value of their investment opportunities. The latter difference might be more relevant to the choice between $B V$ and $N o-B V$ arrangements, and I therefore adjust below the discussion to apply to this case.
} 
an equilibrium, public investors, unable to distinguish between $H$ and $L$ types, will pay the average value to them of a No-BV arrangement. As a result, founders with $H$ firms are not fully capturing the value of the cash flows they confer on public investors by adopting a No- $B V$ arrangement and forgoing their private benefits under $B V$. Consequently, founders with an $H$ firm would have an incentive to deviate from the efficient equilibrium. They would have an incentive to be willing to accept a somewhat lower price at the IPO stage but have a $B V$ arrangement. This incentive to deviate would prevent an efficient pooling equilibrium.

Indeed, under some conditions, the unique equilibrium is one of inefficient pooling in which all founders choose to go public with an inefficient $B V$ arrangement. $L$ firms would have an incentive to follow the $H$ firms and pool with them in the offering of $B V$ arrangements. Even though a $B V$ arrangement is less valuable for founders with $L$ firms, such founders will wish to avoid being identified by IPO investors as an $L$ firm with a lower value.

Thus, the asymmetric information explanation may indicate why IPO firms might adopt $B V$ arrangements that shareholders oppose in midstream. An inefficient pooling might arise at the IPO stage; at the midstream stage, however, shareholders would have no reason to vote for $B V$ arrangements that they know to be inefficient.

To the extent that $B V$ arrangements adopted at the IPO stage are explained by the considered model, the policy implications are similar to those of the agencybased explanations. Under the considered model, No- $B V$ is the optimal default arrangement. Furthermore, it might be beneficial not to allow opting into $B V$ at the IPO stage. A prohibition on such opting-in might move the equilibrium from an inefficient pooling equilibrium--in which all firms offer $B V$--to an efficient pooling equilibrium in which all firms offer $N o-B V$; and both $H$ and $L$ firms will benefit from such a move.

\section{Bounded Attention and Imperfect IPO Pricing}

\section{a. Bounded Attention at the IPO Stage}

Bounded attention arises at the IPO stage when rational buyers do not have unlimited informational and computational capacities. ${ }^{42}$ As such, potential buyers

\footnotetext{
${ }^{42}$ For a detailed explanation of bounded rationality in general, see David M. Kreps, Bounded Rationality, in 1 The New Palgrave Dictionary of Economics and the Law 168 (Peter Newman ed., 1998).
} 
only take into account aspects of the company that are sufficiently salient or important, and other aspects that may have some effect on value are simply not factored into the estimates of value formed by the buyers. ${ }^{43}$

Under the bounded attention explanation of $B V$ arrangements, IPO buyers do not pay attention to the particular choices that companies make among a range of conventional takeover arrangements. IPO buyers might pay attention to some unconventional arrangements or to the adoption of dual-class structure but, as long as the company retains a one-share, one-vote structure, the nuances of takeover provisions are not given weight.

One reason for paying no attention to such nuances is that there is inherently a large degree of uncertainty regarding firms that go public. Such firms have not been subject to the scrutiny and valuation of the market prior to the IPO. Potential IPO buyers thus might concentrate their efforts on assessing the business prospects of the firm going public.

Furthermore, takeover arrangements might be less important at the IPO stage because their effects on shareholders are not immediately relevant. Whether $B V$ will become relevant for shareholders in the future depends on the probability of a move to dispersed ownership. And the adoption of $B V$ will impact shareholders only if and when such a move occurs down the road.

Indeed, at road shows, buyers tend not to inquire about the fine details of firms' corporate charters, so long as those details fall within the established set of arrangements. Buyers do not inquire--and indeed might not even bother to check-whether, say, shareholders can act by written consent, or how quickly shareholders can call a special meeting.

Assuming that IPO buyers do not pay attention to differences among takeover arrangements within a certain set of conventional arrangements, founders have an incentive to gravitate toward the arrangements in this set that protect them most from takeovers. Because founders benefit from such arrangements in terms of

\footnotetext{
${ }^{43}$ The argument of this Section is a particular type of the general argument that capital markets do not usually price each and every corporate provision. For earlier works expressing skepticism about the existence of such pricing, see Robert C. Clark, Agency Costs versus Fiduciary Duties, in Principals and Agents: The Structure of Business 55 (John W. Pratt \& Richard J. Zeckhauser eds., reprint 1991); Lucian Arye Bebchuk, The Debate on Contractual Freedom in Corporate Law, 89 Colum. L. Rev. 1395 (1989); Victor Brudney, Corporate Governance, Agency Costs, and the Rhetoric of Contract, 85 Colum. L. Rev. 1403, 1411-27 (1985). Some of the analysis below draws on Lucian Bebchuk, Freedom of Contract and the Corporation: An Essay on the Mandatory Role of Corporate Law 50-62, Discussion Paper No. 46, Harvard Program in Law and Economics (1988).
} 
expected private benefits of control, it would be rational for them to adopt whatever takeover protections will not cost them in terms of the IPO price. The gravitation during the 1990s toward adoption of staggered boards is consistent with this explanation.

\section{b. Midstream}

Why would shareholders who pay little attention to certain antitakeover provisions in IPO charters vote against them in midstream? One important reason is that, in midstream voting, the issue comes to shareholders in isolation. In the IPO stage, potential buyers have many aspects and dimensions of the company to look at. In contrast, when faced with a vote on a charter amendment to establish a staggered board or on a precatory resolution to de-stagger the board, the only question that shareholders face is whether a staggered board is good for them. Standing in isolation, this question is salient.

Furthermore, at the IPO stage, potential buyers might act on the presumption that, even though conventional antitakeover provisions have a negative expected effect, the effect is not sufficiently significant for them to try to assess its magnitude and factor it into their decision whether to buy shares at the IPO. In contrast, when shareholders face a voting decision, the recognition that the effect of conventional antitakeover provisions is negative, even if small, is sufficient to lead to a nay vote.

It is also worth noting that midstream votes on such questions often come at a stage in which the issue of takeover bids already has more practical significance. Unlike a $B V$ arrangement in a charter at the IPO stage, the effects of a $B V$ arrangement on share price are likely to be directly felt by shareholders by the time a vote on the issue occurs, since the company has already moved to dispersed ownership and the negative effects of $B V$ in terms of entrenchment are thus relevant. The significant discounting for time and the probability of moving to dispersed ownership that might have rendered $B V$ non-salient at the IPO stage are no longer an issue.

Suppose that, if investors were to focus on the subject at the time of the IPO, they would estimate that, in the event the IPO company moves to dispersed ownership down the road, having a $B V$ arrangement would reduce their share value by $1 \%$. The discount of this difference for the time and probability that the company will move to dispersed ownership, along with the fact that other factors are more relevant to an assessment of the IPO value, might cause IPO buyers to pay little attention to the choice between $B V$ and $N o-B V$ arrangements. However, when the same shareholders hold shares in existing companies with dispersed ownership, 
they can be expected to vote against $B V$ in any votes on charter amendments or precatory resolutions.

Thus, because midstream voting is not afflicted with bounded attention problems, the bounded attention explanation is consistent with the persistent midstream voting against $B V$. This pattern can be explained by the fact that, in midstream, the issue of antitakeover provisions comes to a vote in isolation from other issues. Voting against a provision thus requires no more than a qualitative judgment that its impact is negative.

\section{c. Investment Bankers}

A common argument is that the presence of underwriters protects buyers of stock at IPOs and provides them with a reliable signal concerning the quality of the initial charter's provisions. ${ }^{44}$ According to this argument, the underwriter will have an incentive both to study the charter's proposed provisions and to bargain for the optimal provision. The underwriter, as it were, will represent the interests of the buyers of stock. As explained below, however, the existence of underwriters cannot be expected to prevent the inclusion of conventional but inefficient provisions to which buyers do not pay attention. ${ }^{45}$

To examine this argument in our context, suppose that founders take a company public and that they must decide whether to include a charter provision $B V$ that, in the event that the company moves to dispersed ownership down the road, would have an adverse effect of $1 \%$ on the firm's cash flows. Furthermore, suppose that buyers cannot be expected to pay attention to this issue in their IPO purchase decisions. Would the presence of an underwriter, which we can assume knows the effect of $B V$, lead the founders to exclude $B V$ from the company's charter?

The answer is no, because the underwriter would have no incentive to prevent the inclusion of $B V$. In examining the underwriter's incentives, researchers have suggested two reasons why the underwriter might care about the shareholders' interests. First, the underwriter commits itself to purchasing the shares if the public does not, and this commitment gives the underwriter an incentive to make the stock more appealing to the public. But if, by hypothesis,

\footnotetext{
${ }^{44}$ See, e.g., Gilson \& Kraakman, Mechanisms of Market Efficiency, University of Virginia Law Review.

45 The discussion below draws on Bebchuk, Freedom of Contract and the Corporation, supra note 43.
} 
public investors do not pay attention at the IPO stage to the effects of $B V$, the inclusion of $B V$ would not affect the salability of the stock, and therefore the underwriter would have no reason to object to it. That is, the interest of the underwriter--as far as the underwriting commitment is concerned--is solely to cater to the market's demand that is based on the potential buyers' information. The underwriter's interest does not lie in acting on the basis of its own superior information concerning the long-run effects of a $B V$ arrangement.

Second, it is often said that the underwriter has a valuable reputation, and that the underwriter would defend the interests of buyers of stock to prevent damage to its reputation. Whether this reputational element would provide the underwriter with an incentive to oppose $B V$, however, is far from clear. The presence of a reputable underwriter only guarantees to buyers that charter provisions are not misleading or value-reducing in some unconventional, hidden ways. The reputable underwriter's presence does not guarantee that the charter excludes non-optimal but conventional provisions.

\section{F. Private vs. Social Optimality}

Before concluding my exploration of possible explanations for the observed patterns, I should note one factor that might well be at work but that cannot explain the observed combination of IPO and midstream behavior. There is literature showing that socially inefficient restrictions on control contests might be adopted at the IPO because such restrictions might impose a negative externality on outside bidders. ${ }^{46}$ Because such bidders are not "at the table" during the IPO, designers of the IPO charter have no reason to take their interests into account. Although extracting a higher premium from outside bidders would be merely a transfer from a social point of view, it would be desirable from the private perspective of the target's shareholders. Thus, shareholders might prefer a socially undesirable arrangement that inefficiently reduces the likelihood of a takeover but raises premia. It follows that, on the margin, shareholders prefer to restrict takeovers more than is socially optimal.

\footnotetext{
46 See Sanford J. Grossman \& Oliver D. Hart, Takeover Bids, the Free-Rider Problem, and the Theory of the Corporation, 11 Bell J. Econ. 42, 43 (1980); Lucian A. Bebchuk \& Marcel Kahan, A Framework for Analyzing Legal Policy Toward Proxy Contests, 78 Cal. L. Rev. 1073, 1073 (1990); Lucian A. Bebchuk \& Luigi Zingales, Ownership Structures and the Decision to Go Public in Concentrated Corporate Ownership 55, 55 (Randall M. Morck, ed. 2000).
} 
The above analysis implies that, even if standard antitakeover provisions were desired by shareholders, there would be possible grounds for not permitting some such provisions. The evidence, however, indicates that shareholders do not in fact prefer to have these provisions. If the effect of these provisions on expected future premia were sufficient to make them desirable for shareholders, shareholders of existing companies would not systematically oppose the midstream adoption of such provisions. Opposition of these shareholders indicates that they do not judge the effect of these provisions on surplus extraction from bidders sufficient to make them beneficial overall for shareholders.

While the externality point cannot by itself explain the pattern under consideration, it is relevant to the discussion of policy implications. My analysis abstracts from effects on bidders and, as will be discussed below, still reaches a skeptical position toward complete contractual freedom to adopt antitakeover arrangements. Because the externality issue suggests an additional social cost of such arrangements, it reinforces this position.

\section{E. IPO Firms with Private Equity Funding}

In an article focusing on the adoption of antitakeover charter provisions by IPO firms backed by private equity funding, Michael Klausner questions whether the explanations I put forward in this paper are applicable to such firms, and he also proposes an explanation that in his view can account for the behavior of such firms. ${ }^{47}$ As I discuss below, however, the explanation that Klausner puts forward is one that in fact has to rely on one of the explanations that I put forward.

Klasuner questions whether my explanations are applicable to VC-backed IPO firms (i.e., firms that received earlier funding from one or more venture capital firms) on grounds that, when such firms go public, their founder-manager commonly holds a minority of the shares and the venture capitalist(s) hold a majority of the shares. In such circumstances, the explanation based on inducement to de-concentrate ownership is indeed inapplicable because the company is expected not to have a controlling block once the $\mathrm{VC}(\mathrm{s})$ unload their shares in the market, which they commonly do before too long.

Klasuner argues, however, that the explanations based on efficient rent protection and asymmetric information are also inapplicable to VC-backed IPO firms. These explanations assume that those making the decision whether to adopt a $\mathrm{BV}$-arrangement take into account the arrangement's effect on the manager's private

\footnotetext{
${ }^{47}$ Klausner, supra, at section IV.
} 
benefits of control. But, Klausner argues, when a VC holds a majority of shares in the IPO firm, the manager who is going to obtain private benefits of control does not have a decisive say over IPO design.

In Klausner's view, the reason why VC firms permit the inclusion of antitakeover arrangements even though they will not directly share any part of management's private benefits of control is that they wish to maintain their reputation of "management-friendly." Having a reputation of treating well management, especially successful management, in turn helps VCs attract firms in which they could invest. To incorporate this element in the simple model, we need to add a venture capital financing stage, $\mathrm{T}_{\mathrm{VT}}$, that comes before $\mathrm{T}_{0}$, the time in which the firm goes public. According to the proposed story, when the founder-manager and the $\mathrm{VC}$ contract at $\mathrm{T}_{\mathrm{VT}}$, the $\mathrm{VC}$ makes an implicit commitment, backed by the $\mathrm{VC}^{\prime}$ 's reputation, to permit the founder-manager to adopt a BV-arrangement in the fortunate event that the firm end sup going public. Having a reputation for acting in this way is supposed to help the VC attract a deal flow and compete with other VCs.

The reputation argument can explain why the $\mathrm{VC}$ can at $\mathrm{T}_{\mathrm{VT}}$ make its commitment implicit rather than in a legally binding form. Black and Gilson argue that, being repeat players, $\mathrm{VC}^{\prime}$ s are able to make various understandings they have with managers implicit, enforced only by a reputational sanction. ${ }^{48}$ But this still leaves the question of what implicit commitments will be optimal for a VC to make at $\mathrm{T}_{\mathrm{VT}}$.

Standard and familiar reasoning suggests that, at $\mathrm{T}_{\mathrm{VT}}$, a VC will have an incentive to make implicit commitments only to actions down the road that can be expected to increase rather than decrease the expected joint surplus of the parties. Suppose that, in the event of an IPO, adopting a BV-arrangement will produce an overall benefit of $\$ 100$ million to the manager and an overall loss of $\$ 50$ million to the VC. In such a case, the VC will have an incentive to commit at $\mathrm{T}_{\mathrm{VT}}$ to permit a $\mathrm{BV}$-arrangement should the company go public later on even though at that stage a $\mathrm{BV}$-arrangement would produce a loss of $\$ 50$ million to the VC.

Having such an implicit commitment, however, would not be in the parties' and the VC's interest if it is expected that, in the event of an IPO, adopting a BVarrangement will produce an overall benefit of $\$ 100$ million to the manager and an overall loss of $\$ 200$ million to the VC. In such a case, a commitment to permit a BVarrangement in the event of an IPO would in fact reduce the parties' expected joint surplus from the transaction.

48 See Bernard S. Black and Ronald J. Gilson, Venture Capital and the Structure of Capital Markets: Banks versus Stock Markets, 47 J. Fin. Econ. 243 (1998). 
Thus, the introduction of VC reputation and commitment is not by itself sufficient to explain the adoption of BV-arrangements by VC-backed IPO firms. One needs in addition to explain why adopting a BV-arrangement thinking about them as a group at $\mathrm{T}=0$, the joint interest of the parties would be served by having antitakeover provisions. It is only in this case that $\mathrm{VC}$ would have an incentive to maintain a reputation of allowing BV arrangements at the IPO stage.

What can explain why VC(s) and the manager - the pre-IPO shareholderswill be made better off as a group by adopting a BV-arrangement at the IPO stage? The possible explanations are those that my analysis has identified. A BVarrangement could be in the interest of the pre-shareholders as a group under the efficient rent protection explanation, the asymmetric information explanation, or the bounder attention explanation. In short, rather than being inapplicable to the VCbacked firm context, the explanations I put forward are an essential complement to the reputational story Klausner seeks to use for explaining why VC's are willing to go along with BV-arrangements when they have considerable say over IPO design.

\section{CONCLUSION}

While IPO firms have increasingly been adding antitakeover provisions tot heir charters, shareholders of existing companies have increasingly been voting in opposition to such charter provisions. This paper identifies and analyzes possible

explanations for this empirical pattern. The explanations that have been developed can provide a basis for future empirical work and policy analysis in this area. 